\title{
Excitatory Effects of Thyrotropin-Releasing Hormone in the Thalamus
}

\author{
Christian Broberger and David A. McCormick \\ Kavli Institute for Neuroscience and Department of Neurobiology, Yale University School of Medicine, New Haven, Connecticut 06510
}

The activity of the thalamus is state dependent. During slow-wave sleep, rhythmic burst firing is prominent, whereas during waking or rapid eye movement sleep, tonic, single-spike activity dominates. These state-dependent changes result from the actions of modulatory neurotransmitters. In the present study, we investigated the functional and cellular effects of the neuropeptide thyrotropin-releasing hormone (TRH) on the spontaneously active ferret geniculate slice. This peptide and its receptors are prominently expressed in the thalamic network, yet the role of thalamic TRH remains obscure. Bath application of TRH resulted in a transient cessation of both spindle waves and the epileptiform slow oscillation induced by application of bicuculline. With intracellular recordings, TRH application to the GABAergic neurons of the perigeniculate (PGN) or thalamocortical cells in the lateral geniculate nucleus resulted in depolarization and increased membrane resistance. In perigeniculate neurons, this effect reversed near the reversal potential for $\mathrm{K}^{+}$, suggesting that it is mediated by a decrease in $\mathrm{K}^{+}$conductance. In thalamocortical cells, the TRH-induced depolarization was of sufficient amplitude to block the generation of rebound $\mathrm{Ca}^{2+}$ spikes, whereas the even larger direct depolarization of PGN neurons transformed these cells from the burst to tonic, single-spike mode of action potential generation. Furthermore, application of TRH prominently enhanced the afterdepolarization that follows rebound $\mathrm{Ca}^{2+}$ spikes, suggesting that this transmitter may also enhance $\mathrm{Ca}^{2+}$-activated nonspecific currents. These data suggest a novel role for TRH in the brain as an intrinsic regulator of thalamocortical network activity and provide a potential mechanism for the wake-promoting and anti-epileptic effects of this peptide.

Key words: burst firing; current clamp; $\mathrm{Ca}^{2+}$-activated nonspecific (CAN) current; epilepsy; neuropeptide; seizure

\section{Introduction}

The activity and signaling characteristics of the thalamus are state dependent because of the intrinsic properties of its cells, their connections, and the state of modulatory influences (Deschênes et al., 1984; Jahnsen and Llinás, 1984a,b; Steriade et al., 1993; McCormick and Bal, 1997). In the awake attentive animal, thalamocortical neurons are relatively depolarized, discharge almost exclusively in the single-spike firing mode, and faithfully transfer inputs from the sensorium. With the transition to slowwave sleep, thalamic neurons hyperpolarize and increasingly replace single-spike discharge with rhythmic burst firing, such as spindle waves (McCarley et al., 1983; Domich et al., 1986; Steriade et al., 1986, 1993). Spindle waves are observed in the electroencephalogram (EEG) as waxing and waning 6-15 Hz oscillations (Steriade et al., 1993). This activity is generated as an interaction between GABAergic neurons of the reticular thalamic/perigeniculate nuclei (nRt/PGN) and thalamocortical neurons (von Krosigk et al., 1993; Bal et al., 1995a,b). Interestingly, blockade of the $\mathrm{GABA}_{\mathrm{A}}$ receptor transforms spindle waves into a "par-

Received Aug. 4, 2004; revised Dec. 28, 2004; accepted Dec. 31, 2004.

This work was supported by the National Institutes of Health, the Human Frontiers Science Program, and the Kavli Center for Neuroscience at Yale (D.A.M.). C.B. is supported by a postdoctoral grant from the Wenner-Gren Foundation (Sweden) and the Swedish Royal Academy of Sciences and is a Fulbright visiting scholar.

Correspondence should be addressed to David A. McCormick, Department of Neurobiology, Yale University School of Medicine, 333 Cedar Street, New Haven, CT 06510. E-mail: David.McCormick@yale.edu.

C. Broberger's present address: Department of Neuroscience, Karolinska Institutet, 17177 Stockholm, Sweden. DOI:10.1523/JNEUROSCI.3198-04.2005

Copyright $\odot 2005$ Society for Neuroscience $\quad$ 0270-6474/05/251664-10\$15.00/0 oxysmal" $3 \mathrm{~Hz}$ oscillation, which shares characteristics with childhood absence epilepsy spike-wave activity (von Krosigk et al., 1993; Bal et al., 1995a,b; Steriade and Contreras, 1998; Huntsman et al., 1999; McCormick and Contreras, 2001). These and other findings (Kostopoulos et al., 1981; Liu et al., 1991; Huguenard and Prince, 1994) indicate that the thalamus may exist in multiple, behaviorally relevant states.

Activity within thalamocortical networks is tightly regulated by several neurotransmitters (McCormick and Bal, 1997). In addition to classic neurotransmitters, peptides also play an important role in controlling the firing mode of thalamic neurons. These peptides include cholecystokinin (Cox et al., 1995, 1997; Lee and McCormick, 1997), neuropeptide Y (Sun et al., 2001a,b), somatostatin (Leresche et al., 2000; Sun et al., 2002), nociceptin (Meis et al., 2002), pituitary adenylate cyclase-activated peptide, and vasoactive intestinal peptide (Lee and Cox, 2003; Sun et al., 2003).

The neuropeptide thyrotropin-releasing hormone (TRH), first discovered as a hypophysiotropic hormone (Boler et al., 1969; Burgus et al., 1969), is strongly expressed in the nRt (Lechan et al., 1986; Segerson et al., 1987; Burgunder et al., 1999; Heuer et al., 2000). Furthermore, prominent TRH receptor (TRHR) expression occurs in thalamic relay nuclei (Cao et al., 1998; Heuer et al., 2000; O’Dowd et al., 2000). Yet despite the documented presence of signaling components, a role for TRH within the thalamocortical circuitry remains to be determined; however, clinical and experimental reports suggest that both ep- 
ileptic discharge and sleep can be modulated by TRH (Nemeroff et al., 1975; Matsumoto et al., 1987; Ujihara et al., 1991; Momiyama et al., 1996; Nishino et al., 1997).

Here we investigated the effects of TRH in slices from the ferret geniculate complex, containing both the dorsal lateral geniculate nucleus (LGNd) and the PGN. This in vitro thalamic network displays spontaneous spindle-wave activity with characteristics similar to those observed in vivo during slow-wave sleep (von Krosigk et al., 1993; Bal et al., 1995a,b). We show that TRH can control the generation of spindle waves and the firing mode of thalamic neurons by modulating resting membrane potential and the amplitude of afterdepolarizing currents (Broberger and McCormick, 2002).

\section{Materials and Methods}

For the preparation of slices, male and female ferrets, $\sim 3$ months old, were anesthetized deeply with sodium pentobarbital $(30 \mathrm{mg} / \mathrm{kg})$ and killed by decapitation. Animal procedures were performed in accordance with Yale University Medical School guidelines for the use of animals in research. The forebrain was removed rapidly, and the hemispheres were separated with a midline incision. Sagittal slices ( $400 \mu \mathrm{m}$ thick) containing the lateral geniculate/perigeniculate complex were prepared on a Vibratome (Leica, Nussloch, Germany). A modification of the technique developed by Aghajanian and Rasmussen (1989) was used to increase tissue viability. During preparation of slices, the tissue was placed in an ice-cold solution in which $\mathrm{NaCl}$ was replaced with sucrose while an osmolarity of 307 mOsm was maintained. After preparation, slices were placed in an interface-style recording chamber (Fine Sciences Tools, Foster City, CA) and allowed to recover for a minimum of $2 \mathrm{~h}$. The bathing medium contained (in mM) $124 \mathrm{NaCl}, 2.5 \mathrm{KCl}, 2.0 \mathrm{MgSO}_{4}, 1.25$ $\mathrm{NaH}_{2} \mathrm{PO}_{4}, 2.0 \mathrm{CaCl}_{2}, 26 \mathrm{NaHCO}_{3}$, and 10 dextrose and was aerated with $95 \% \mathrm{O}_{2} / 5 \% \mathrm{CO}_{2}$ to a final $\mathrm{pH}$ of 7.4 . For the first $20 \mathrm{~min}$ that the geniculate slices were in the recording chamber, the bathing medium contained an equal mixture of the normal $\mathrm{NaCl}$ and the sucrosesubstituted solutions. Bath temperature was maintained at $34-35^{\circ} \mathrm{C}$. The presence of spontaneous spindling activity was determined in all slices by means of extracellular multiple-unit recordings.

Extracellular recordings were obtained with low-resistance $(<1 \mathrm{M} \Omega)$ tungsten microelectrodes (Frederick Haer Corporation, Bowdoinham, ME) and bandpass filtered between $\sim 300$ and $10,000 \mathrm{~Hz}$. Spindle waves are discrete events and remain so also in the dysrhythmic state induced by $10 \mathrm{~nm}$ TRH. The recording was divided into 100 s periods, and the number of spindle waves within each period was counted by way of visual inspection. Spindles waves displayed a minimal duration of $2 \mathrm{~s}$, and a full return to baseline was required to separate one spindle wave from the succeeding one. To investigate the bicuculline-induced slow oscillation, these were initiated by brief ( 10 shocks at $100 \mathrm{~Hz}$ ) stimulation of afferent fibers via a concentric stimulating electrode placed in the optic radiation. Intracellular recording electrodes were formed on a Sutter Instruments (Novato, CA) P-80 micropipette puller from medium-walled glass (1BF100-4; World Precision Instruments, Sarasota, FL) and beveled on a Sutter Instruments beveller to 60-120 M $\Omega$ impedance. Micropipettes were filled with $2 \mathrm{M} \mathrm{K}$-acetate. Cells were included in the study if they exhibited input resistances of at least $30 \mathrm{M} \Omega$ (average: $61 \pm 26 \mathrm{M} \Omega$ for LGNd cells, $n=35 ; 107 \pm 60 \mathrm{M} \Omega$ for PGN cells, $n=9$ ) and stable resting membrane potential for at least $10 \mathrm{~min}$ (typically $45-120 \mathrm{~min}$ ) and were able to generate a repetitive barrage of action potentials with the intracellular injection of depolarizing current. For both extracellular and intracellular recordings, electrodes/micropipettes were placed either in the LGNd A-laminas or in the PGN, which were readily visible with epiillumination of the living geniculate slice.

Drugs were applied either via the bath solution (bath application) or locally with the pressure-pulse technique in which the delivery of a brief pulse of nitrogen $(10-100 \mathrm{~ms}, 200-350 \mathrm{kPa})$ was applied to a broken micropipette containing the drug dissolved in bath solution to extrude volumes of 2-20 pl. During local application, the preformed TRH picodrop at the tip of the micropipette end was gently applied to the surface of the slice within $50 \mu \mathrm{m}$ of the entry point of the recording electrode. In control experiments, such application of slice solution did not affect electrical properties or firing patterns of cells. TRH (Phoenix Pharmaceuticals, Belmont, CA), (-)-bicuculline methiodide (RBI, Natick, MA), and acetyl- $\beta$-methylcholine chloride (Sigma, St. Louis, MO) were dissolved in the recording solution to final concentrations. For data acquisition and analysis, Spike 2, version 4, software (Cambridge Electronic Design, Cambridge, UK) was used.

\section{Results}

Extracellular multiunit recordings from the A-laminas of the ferret LGNd slice in vitro revealed the spontaneous occurrence of spindle waves (Figs. 1, 2A), in agreement with previous reports (von Krosigk et al., 1993). Spindle waves appeared as 2- to 4-slong episodes characterized by waxing and waning rhythmic bursting discharge patterns with an intraspindle frequency of 7-8 $\mathrm{Hz}$ (Figs. $1 B, 2 A$ ). Bath application of $50 \mathrm{~nm}$ TRH resulted in a relatively abrupt cessation of spindle-wave activity within 5-7 min, sometimes preceded by one or two attenuated spindle waves $(n=5)$ (Fig. 1A,C). Occasionally, the loss of spindle waves was accompanied by increased tonic background firing. In one experiment, spindle waves persisted, albeit highly decreased in amplitude, duration, and rhythmicity. When spindle waves reappeared after washout (typically after $10 \mathrm{~min}$ ), inter-spindle interval was initially shorter and more variable than under control conditions, but gradually assumed the same, rhythmic configuration as seen before drug application (Fig. 1A,D). A second application of $\mathrm{TRH}$ to a slice preexposed to this peptide resulted in a much attenuated response as compared with the initial drug application (data not shown) $(n=2)$. Interestingly, with prolonged bath application of TRH, the spindle oscillation returned slowly, typically within 10-20 min, although at lower spindle frequency and at times with sustained tonic firing in between spindles (Fig. $1 E$ ) $(n=5)$. Concentrations $>50 \mathrm{nM}$ (up to $5 \mu \mathrm{M})$ also caused reversible cessation of spindling activity (data not shown) $(n=5)$. In contrast, bath application of a lower concentration of TRH (10 $\mathrm{nM}$ ) resulted in an increased frequency of occurrence of spindle waves (control, $5.6 \pm 0.3$ spindle waves per $100 \mathrm{~s}$; TRH, $10.3 \pm$ 2.5 spindle waves per $100 \mathrm{~s})$ (Fig. $1 F)(n=5)$ accompanied by a decrease in the regularity of spindle periodicity and the appearance of single cell bursting discharges of $\sim 2 \mathrm{~Hz}$ frequency (intraburst frequency $\sim 300 \mathrm{~Hz}$ ) (Fig. 1, Fb') preceding spindle waves. There was no significant change in intra-spindle frequency ( $7.6 \pm$ $0.3 \mathrm{~Hz}$, pre-TRH; $7.9 \pm 0.4 \mathrm{~Hz}$, post-TRH), although the duration of spindle waves was shortened by an average of $24 \%$. The increase in rate of recurrence of spindle waves was caused by a shortening of inter-spindle wave intervals, which may have resulted secondarily in the decrease in spindle-wave duration.

We have shown previously that bath application of the $\mathrm{GABA}_{\mathrm{A}}$ receptor antagonist [and blocker of some $\mathrm{K}_{\mathrm{Ca} 2+}$ channels (Debarbieux et al., 1998)] bicuculline-methiodide can transform spindle waves into 2-3 Hz synchronized network discharges (von Krosigk et al., 1993; Bal et al., 1995a,b). To examine whether the application of TRH may disrupt these bicuculline-induced oscillations, we first evoked spindle waves with brief stimulation to the optic radiation (10 stimuli; $100 \mu$ s duration; $40-400 \mu \mathrm{A}$ amplitude; $100 \mathrm{~Hz}$ frequency) (Fig. 2A). Bath application of bicuculline-methiodide $(25 \mu \mathrm{M})$ resulted in a shift of the evoked $7 \mathrm{~Hz}$ spindle waves to a slow oscillation of $\sim 2-3 \mathrm{~Hz}$ (Fig. $2 A, B$ ). Bath application of TRH (200 nM) resulted, within 10-20 min, in a complete cessation $(n=3$ of 6$)$ or marked decrease in duration (from $10.0 \pm 3.0$ to $3.6 \pm 0.6 \mathrm{~s} ; n=3$ of 6 ) of the bicucullineinduced slow oscillation (Fig. $2 C$ ). Similar to the multiunit recordings described above, TRH bath application often resulted in 
A

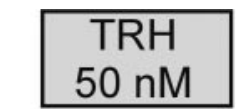

Spindle waves

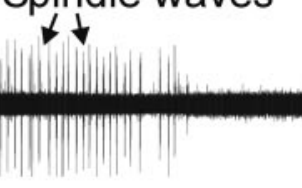

B

C
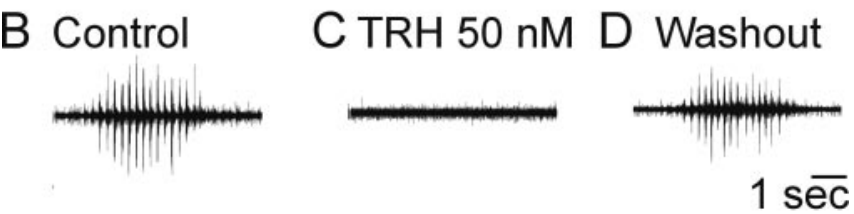

E

Control

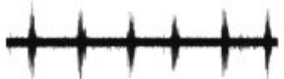

$5 \mathrm{~min}$ TRH $50 \mathrm{nM}$

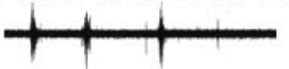

$10 \mathrm{~min}$

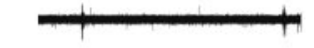

\section{$20 \mathrm{~min}$}
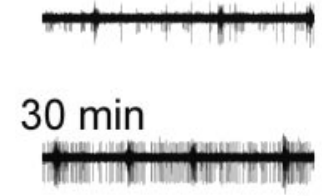

$20 \overline{\mathrm{sec}}$
Spindle waves

$\downarrow$

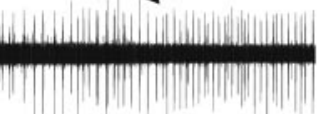

D

$\overline{5 \min }$
$1 \mathrm{sec}$

$\mathrm{F}$

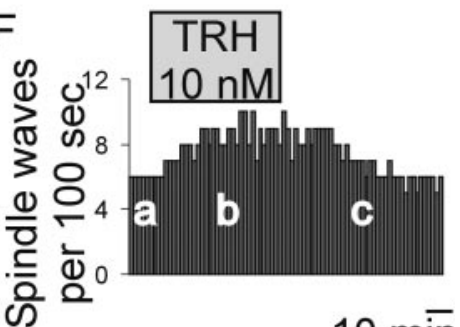

$10 \mathrm{~min}$

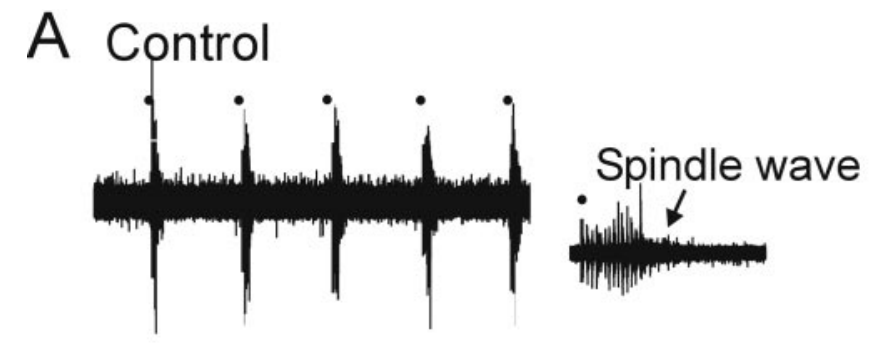

B Bicuculline

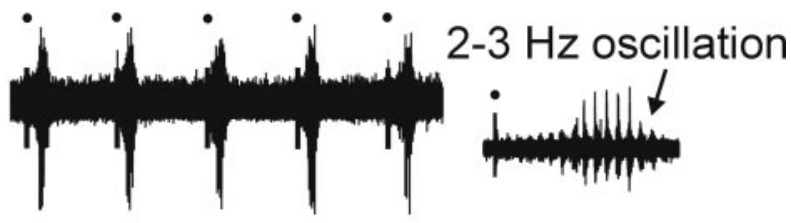

C Bicuculline $+\mathrm{TRH}$

\section{Bicuculline (TRH washout)}

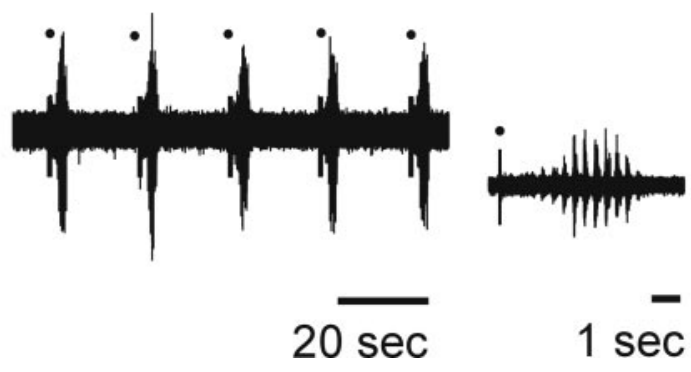

Figure 2. TRH inhibits the $3 \mathrm{~Hz}$ oscillation induced by $G_{A B A_{A}}$ receptor blockade. Extracellular multiunit activity in the LGNd in which spindle waves and the bicuculline-induced slow oscillation are elicited by electrical stimulation of the optic radiation $(-)$. $A$, Under control conditions, $7 \mathrm{~Hz}$ spindle waves appear in response to afferent stimulation. $B$, Bath application of the $G_{A B A_{A}}$ receptor antagonist bicuculline methiodide $(25 \mu \mathrm{M})$ slows the oscillation frequency to a $2-3 \mathrm{~Hz}$ network rhythm. C, When TRH (200 nm) is also added to the bath solution, the bicucullineinduced slow oscillation disappears, but it recovers after TRH is washed out (D). waves, which resume with washout. $B-D$, Expansions of portions of the recording in $A$ showing the spindle waves before and after TRH and the lack of spindles during TRH application. $E_{i}$ Multiunit recording at different intervals after beginning of TRH ( $50 \mathrm{~nm}$ ) bath application. With sustained delivery of the peptide, spindle waves reappear (20 min in TRH), albeit now less robustly. F, Bath application of a lower concentration (10 nM) of TRH causes a reversible increase in spindle-wave frequency. Top histogram shows number of spindle waves per $100 \mathrm{~s}$; the recording was divided into $100 \mathrm{~s}$ periods, and the number of spindles waves within each period was counted by way of visual inspection. Spindles waves displayed a minimal duration of $2 \mathrm{~s}$, and a full return to baseline was required to separate one spindle wave from the succeeding one. Bottom traces $(a-c)$ are examples of the raw recording taken at different intervals as indicated in histogram. Rhythmic bursting is observed during application of $10 \mathrm{~nm} \mathrm{TRH} \mathrm{(Fb);} \mathrm{inserted}$ expansion ( $\mathrm{Fb}^{\prime}$ ) illustrates one such burst consisting of high-frequency discharge at $\sim 300 \mathrm{~Hz}$.

an increase in the (often low amplitude) background tonic discharge. After washout of TRH, the slow, $2-3 \mathrm{~Hz}$ oscillation returned (Fig. 2D).

In the LGNd slice in vitro, some types of local GABAergic interneurons can be recognized by their spontaneous steady discharge at $5-15 \mathrm{~Hz}$, their relatively short-duration action potentials, and a strong inhibitory response to the activation of musca-

rinic receptors (McCormick and Pape, 1988; Pape and McCormick, 1995). Here we examined the effects of TRH on the spontaneous discharge of 11 putative local GABAergic interneurons in the LGNd identified according to the criteria above (spike width at half-amplitude $0.20 \pm 0.10 \mathrm{~ms}$ ) (Fig. 3). Local application of the muscarinic agonist acetyl- $\beta$-methylcholine ( $5 \mathrm{~mm}$ in micropipette) to such presumed GABAergic interneurons in the LGNd resulted in a pronounced period of inhibition of actionpotential discharge, as reported previously (Fig. 3A) (McCormick and Pape, 1988). Local application of TRH (5 $\mu \mathrm{M}$ in micropipette) in the vicinity of the extracellular recording electrode produced no discernible change in the firing pattern of putative interneurons $(n=11)$. In a few of these cases (Fig. 3, compare $B$, C) $(n=3$ of 11), TRH application resulted in the appearance of tonic firing from units that had not been detectable previously. We presume that these cells may be thalamocortical relay neu- 


\section{Lateral Geniculate Nucleus}
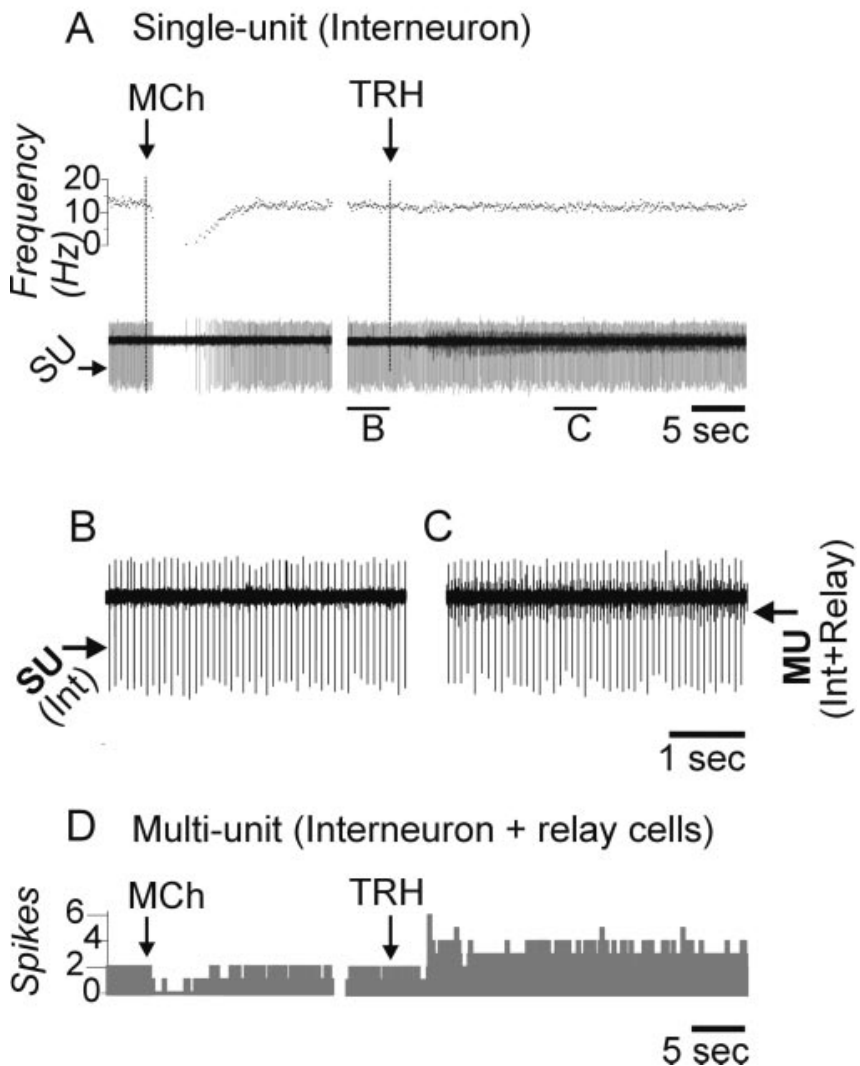

Figure 3. TRH application increases thalamocortical cell discharge but does not affect local interneuron firing rate. $A$, Simultaneous multiunit and single-unit recording in the LGNd. The single unit shows regular $12 \mathrm{~Hz}$ discharge of short-duration spikes that is transiently inhibited by local application of the muscarinic agonist methylcholine (MCh) (5 mM in micropipette). $A$, Bottom trace shows discharge frequency of the large (interneuron) unit; note reversible drop in frequency in response to $\mathrm{MCh}$. These characteristics identify this cell as a putative local interneuron (Pape and McCormick, 1995). Local application of TRH (5 $\mu \mathrm{m}$ in micropipette) does not affect firing frequency of this putative interneuron. $B, C$, Expansions of bottom trace in $A$, showing interneuron (Int) single-unit activity in $B$ and interneuron and presumed thalamocortical cell (Int + Relay) activity in C. D, Histogram shows spike incidence for multiple units determined at detection level indicated in C. (Bin size is $100 \mathrm{~ms}$.) Note increased combined spike incidence in response to TRH; the application of TRH resulted in an increase in activity of the smaller multiunit activity (sampled at a lower amplitude), which presumably represents the activity of a subpopulation of thalamocortical cells.

rons, because those constitute the most abundant cell type in the LGNd. Furthermore, these units produced longer-duration spikes (width at half-amplitude, $0.32 \pm 0.14 \mathrm{~ms}$ ) as compared with the presumed interneurons; in each recording the putative interneuron always exhibited shorter duration action potentials than in those of the putative relay cell. The ratio of "relay" to "interneuron" spike widths at half-amplitude was $1.70 \pm 0.15$ (Pape and McCormick, 1995). In the remaining 8 of 11 recordings, TRH application did not cause tonic firing in neurons, although spindle waves were inhibited.

The cells of the nRt/PGN (Houser et al., 1980; Uhlrich et al., 1991) are another type of GABAergic interneuron in the thalamus. These cells exhibit pharmacological responses distinct from either local GABAergic interneurons or thalamocortical cells (McCormick and Wang, 1991; Pape and McCormick, 1995; Sanchez-Vives et al., 1996). Extracellularly recorded PGN neurons $(n=9)$ discharge repetitive bursts during spindle waves, and

\section{Perigeniculate nucleus}
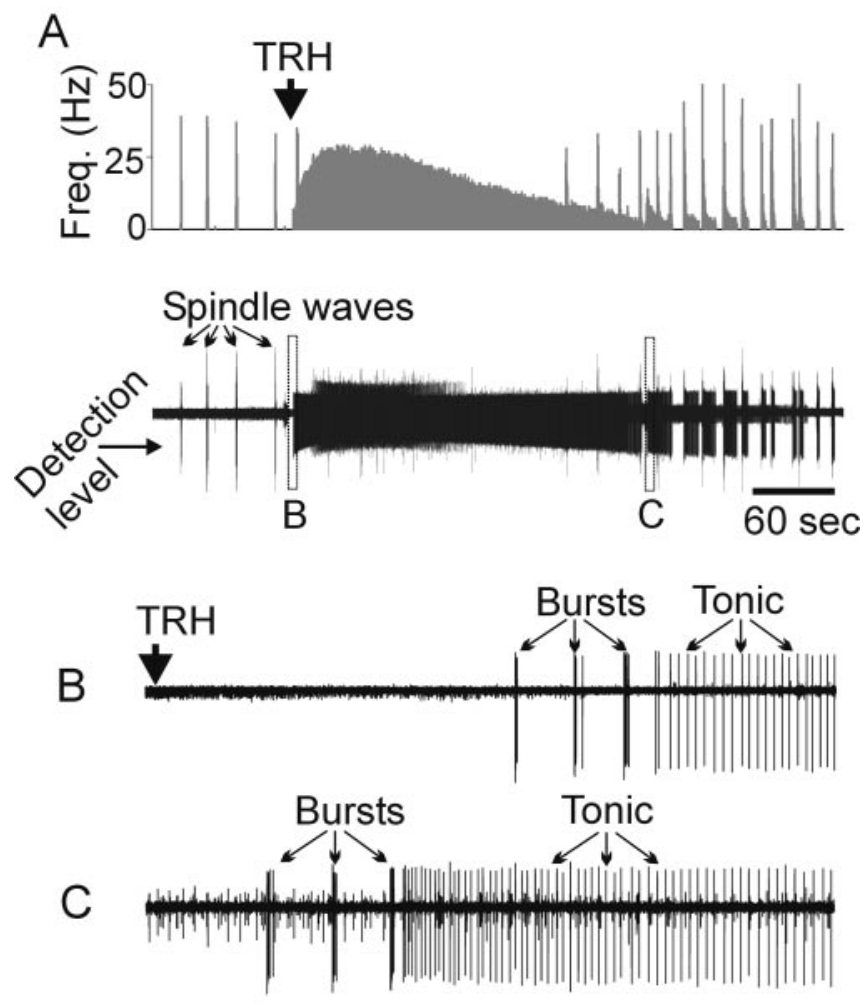

$1 \mathrm{sec}$

Figure 4. TRH application switches $P G N$ neurons from burst to tonic firing. $A$, Extracellular recording from the PGN (bottom trace); top histogram shows spike incidence at detection level indicated in bottom trace. Spindle wave-associated bursting is seen from a single unit at beginning of recording. Local application of TRH ( $1 \mu \mathrm{m}$ in micropipette) results in abrupt cessation of spindle waves and the onset of tonic firing with additional units recruited. Recovery to baseline is characterized by successive cycles of tonic firing preceded by bursts. $B, C$, Expansions of bottom trace in $A$. Note rhythmic bursts preceding tonic discharge immediately after TRH application (B) and during the gradual recovery from TRH application (C).

in some cases, with low-frequency $(<1 \mathrm{~Hz})$ rhythmic bursts in between spindle waves (Fig. 4A-C). Local application of TRH (1 $\mu \mathrm{M}$ in micropipette) to the surface of the slice near the recording site of these units resulted in a cessation of spindle waves and PGN bursting and the appearance of tonic single-spike activity (Fig. 4A,B). This tonic firing increased rapidly and then decreased slowly in frequency, during which spindle waves reappeared. As the tonic discharge slowly decreased, cycles of $1-3 \mathrm{~Hz}$ rhythmic burst discharge followed by tonic activity appeared (Fig. $4 A, C$ ). In addition, the transition from spindling to singlespike activity was often associated with the occurrence of two or three rhythmic bursts (Fig. 4B). This burst-burst-burst-tonic pattern is intrinsic to PGN GABAergic neurons and has been observed previously after recovery from serotonin-induced depolarization (McCormick and Wang, 1991). Typically, spindles and spindle wave-associated bursting in PGN neurons was reestablished after $\sim 3-5 \mathrm{~min}$.

\section{Intracellular recordings of TRH actions in LGNd}

Intracellular current-clamp recordings were obtained from 35 cells in the LGNd, displaying the electrophysiological properties of thalamocortical neurons (Deschênes et al., 1984; Jahnsen and Llinás, 1984a,b; McCormick and Pape, 1988; von Krosigk et al., 
1993). In these cells, spontaneously occurring repetitive $(\sim 7 \mathrm{~Hz})$ barrages of IPSPs characteristic of spindle waves recurred typically every $20 \mathrm{~s}$ and often resulted in rebound low-threshold $\mathrm{Ca}^{2+}$ spikes (LTS) commonly crowned with bursts $(300-400$ $\mathrm{Hz}$ ) of action potentials (Fig. 5A-D) (Deschênes et al., 1984). Local application of TRH (1-5 $\mu \mathrm{M}$ in micropipette) to the LGNd resulted in a slow $(\sim 5$ min duration) depolarization of the membrane potential of thalamocortical cells (average, $+3.5 \pm 1.5 \mathrm{mV} ; n=30$ of 35 ) (Fig. $5 A$ ). A small increase in input resistance (average, $+10.2 \pm 7.8 \% ; n=16$ of 19 ) accompanied the depolarization, determined as an increased voltage deflection in response to hyperpolarizing current pulses after manual compensation for the change in membrane potential (Fig. 5E). Concomitant with depolarization, there was a transient cessation or weakening of spindle waveassociated IPSP barrages (Fig. 5A). In addition, the depolarization was commonly accompanied by either a loss of rebound bursts in response to hyperpolarizing current pulses $(n=5$ of 9 ) or a diminished number of spikes per burst $(n=3$ of 9 ; data not shown). In cells in which the hyperpolarizing pulse elicited an LTS of insufficient amplitude to produce action potentials, the LTS amplitude diminished after TRH application ( $n=4$ of 4$)$. These decreases in rebound $\mathrm{Ca}^{2+}$ spikes or $\mathrm{Ca}^{2+}$-mediated burst discharges appeared to be secondary to the TRH-induced depolarization, because compensation for the change in membrane potential resulted in a full return of rebound $\mathrm{Ca}^{2+}$ spike and burst amplitude and intensity (data not shown; $n=12$ of 12).

Burst discharges in LGNd thalamocortical and PGN neurons are followed by a slow afterdepolarization (ADP) of the membrane potential, which may be generated by a calcium-activated nonselective cation (CAN) current (Figs. 5E, 6) (Bal and McCormick, 1993; Hughes et al., 2002). Local application of TRH (1-5 $\mu \mathrm{M}$ in micropipette) resulted in a marked and long-lasting enhancement of the $\mathrm{Ca}^{2+}$ spike ADP (Figs. 5E, 6). To determine whether the enhanced ADP after TRH application was independent of the depolarization, the amplitude of the hyperpolarizing pulse was adjusted so that a similar voltage deflection was seen in response to the hyperpolarizing pulse both before and after TRH application. In either condition, the presence of TRH resulted in an enhancement of the ADP. In two recorded LGNd cells, TRH application resulted in an enhanced ADP, whereas no increase was seen in apparent input resistance, suggesting that the two phenomena can occur independent of each other. The average increase in the post-Ca ${ }^{2+}$ spike ADP, calculated as area ( $\mathrm{mV}$-ms) under the voltage trace (beginning from the peak of the LTS), was $+45 \pm 23 \%(n=9$; down during the barrage.

\section{Intracellular, LGNd thalamocortical cell}
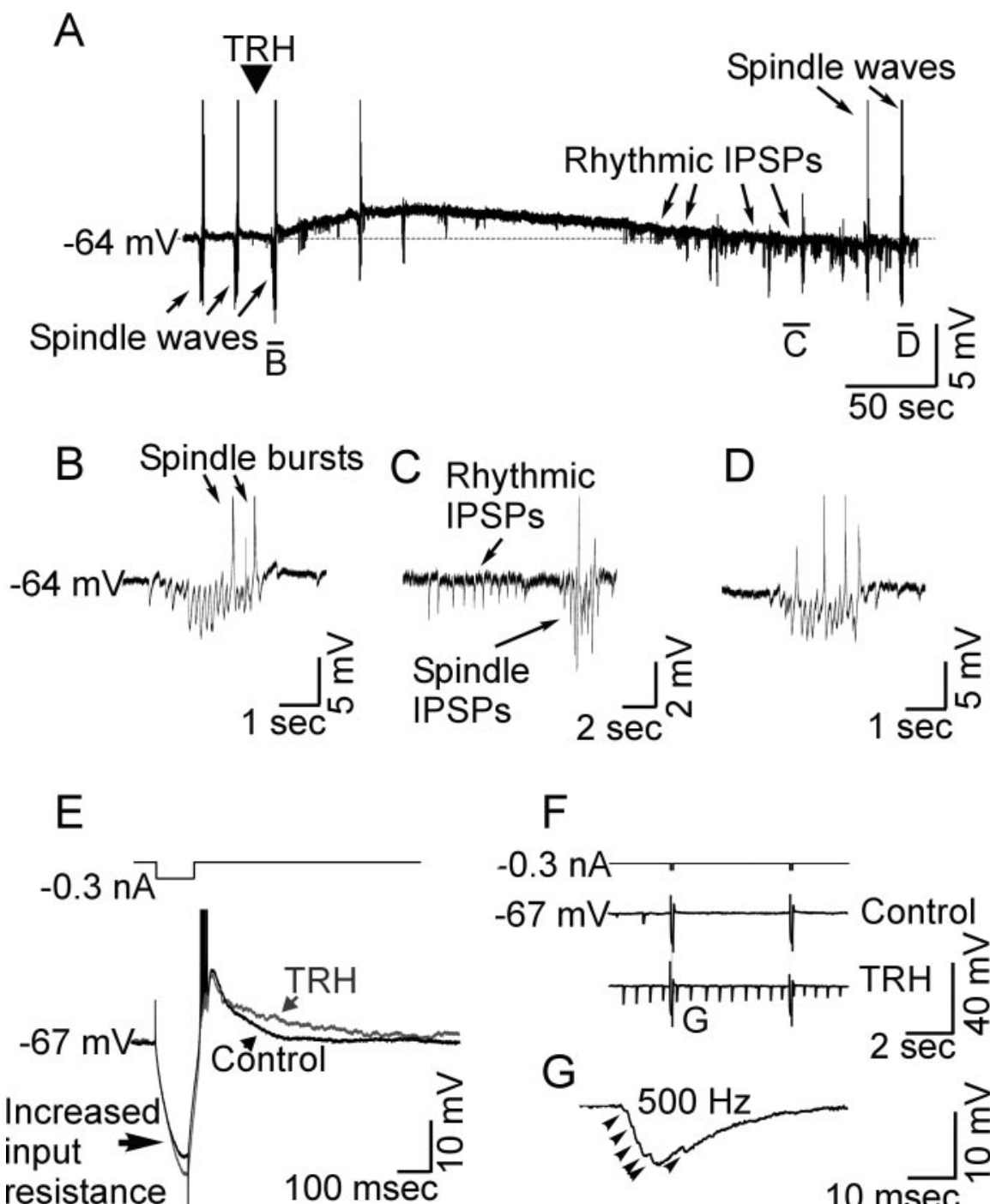

Figure 5. TRH depolarizes thalamocortical neurons and enhances the slow afterdepolarization after $\mathrm{Ca}^{2+}$ spikes. Intracellular recording from an LGNd thalamocortical cell. $A$, Under control conditions, rhythmic IPSP barrages elicit the rebound burst discharges typical of spindle waves. Local application of TRH ( $5 \mu \mathrm{m}$ in micropipette) results in a gradual $3 \mathrm{mV}$ depolarization. IPSP barrages are transiently abolished and show diminished amplitude and duration after return. During the later stages of the response to TRH, rhythmic IPSPs appear that are separate from spindle waves. $B$, Expansion of trace in $A$ shows an intracellularly recorded spindle wave. C, Examples of rhythmic IPSPs occurring during the late stage of TRH action. D, Recovery of spindle waves. $E$, The application of TRH caused a small increase in apparent input resistance. TRH also enhances the slow afterdepolarization after a rebound low-threshold $\mathrm{Ca}^{2+}$ spike. (Action potential traces in $A-E$ have been truncated for clarity.) $F$, Example of rhythmic IPSP barrages arriving at $\sim 2 \mathrm{~Hz}$ in a thalamocortical cell in response to TRH. Under control circumstances, IPSP barrages are rare. $G$, Expansion of one compound IPSP illustrating that it is composed of IPSPs arriving at $\sim 500 \mathrm{~Hz}$, but in which the frequency slows

$p<0.01)$. This measurement of the ADP necessarily includes a portion of the LTS, although the ADP forms the largest component by far.

One characteristic of the CAN current is that it is not supported by $\mathrm{Sr}^{2+}$ ions, although these do support the LTS. To examine whether the slow ADP after a rebound $\mathrm{Ca}^{2+}$ spike in thalamocortical neurons may be mediated by a CAN current, we substituted $\mathrm{Sr}^{2+}$ for $\mathrm{Ca}^{2+}$ in the extracellular solution. When calcium chloride $(2 \mathrm{~mm})$ in the recording solution was replaced by strontium chloride ( $2 \mathrm{~mm})$, the LTS and bursts of action potentials remained, but the slow ADP was abolished (Fig. 6) $(n=$ 4). In addition, TRH application no longer exhibited an enhanc- 

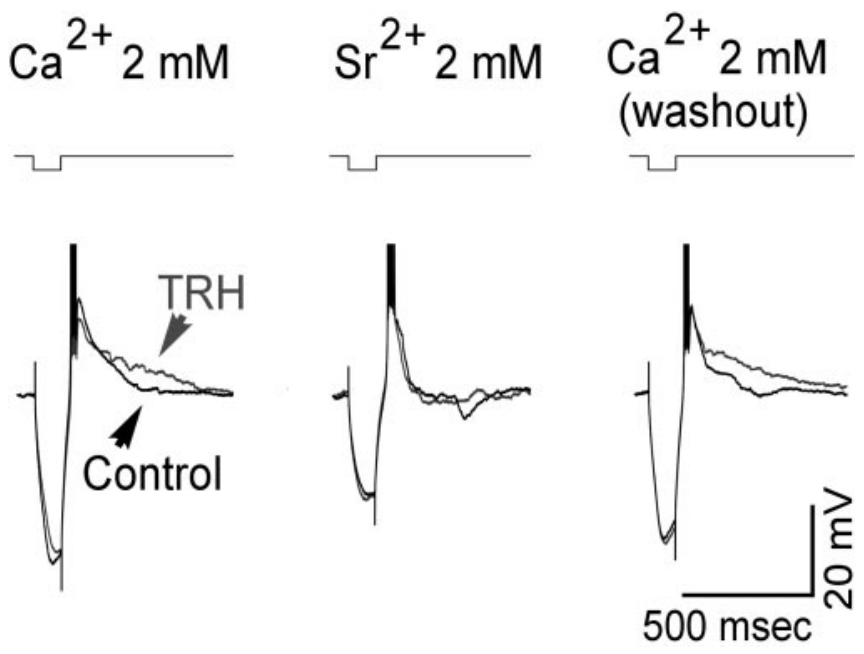

Figure 6. TRH enhances the slow afterdepolarization after $\mathrm{Ca}^{2+}$ spikes; $\mathrm{Sr}^{2+}$ abolishes this effect. Rebound bursts elicited by hyperpolarizing current pulses are followed by an ADP in $2 \mathrm{mM}$ $\mathrm{Ca}^{2+}$. The amplitude of the current pulses was set to produce similar amplitudes of hyperpolarization in the absence and presence of TRH. Local application of TRH ( $5 \mu \mathrm{m}$ in micropipette) results in an enhancement of the ADP (left trace). Substituting $\mathrm{Ca}^{2+}$ in the recording solution with $\mathrm{Sr}^{2+}$ blocks the slow ADP and prevents the TRH-induced augmentation (middle trace). When normal $\mathrm{Ca}^{2+}$ concentration is restored $\left(\mathrm{Sr}^{2+}\right.$ washout; right trace), the ADP returns, and it is again enhanced by TRH. (Action potential traces have been truncated for clarity.)

ing effect on the late phases of the rebound spike (average, $+2 \pm$ $8 \% ; n=4)$ (Fig. 6). With subsequent washout of $\mathrm{Sr}^{2+}$ and reinstatement of a control $\mathrm{Ca}^{2+}$ concentration, the TRH-induced enhancement of the ADP returned (Fig. 6). In contrast to the block by $\mathrm{Sr}^{2+}$ of the slow ADP, both the depolarizing response and the increase in input resistance in response to TRH application could still be observed during perfusion with the strontiumcontaining solution $(n=4)$.

In approximately one-half $(n=17$ of 35$)$ of the LGNd thalamocortical neurons, TRH application resulted in the appearance of rhythmic barrages of IPSPs (Fig. 5A,C,F). These barrages typically arrived late in the response to TRH, in comparison with the depolarization and enhancement of the post-Ca ${ }^{2+}$ spike ADP. Notably, under control conditions, similar barrages of IPSPs were rarely seen (except as spindle-associated IPSP barrages) and then only as solitary phenomena. The TRH-induced IPSP barrages occurred rhythmically at $\sim 2 \mathrm{~Hz}$ and were composed of a burst of individual IPSPs arriving at $200-500 \mathrm{~Hz}$, with the frequency of arrival decreasing within the burst (Fig. 5D). This pattern of IPSP barrages is highly suggestive of rhythmic burst firing in a presynaptic GABAergic neuron after the application of TRH, much as is shown for the PGN cell in Figure 4C. Finally, a second application of TRH to LGNd neurons, within $\sim 30$ min of the first application, generally resulted in an attenuated response, i.e., a smaller depolarization and a less pronounced enhancement of the ADP (data not shown; $n=8$ ), indicating desensitization.

\section{Intracellular recordings of TRH actions in the PGN}

The PGN was visually identified and intracellular current-clamp recordings were obtained from neurons exhibiting the electrophysiological features of PGN cells $(n=19)$ (von Krosigk et al., 1993; Bal et al., 1995b). Under control conditions, 6-7 Hz barrages of EPSPs arrived at regular intervals of $\sim 20$ s to elicit burst discharges characteristic of spindle waves in PGN neurons (Fig. $7 A, B)$. Local application of TRH ( $1 \mu \mathrm{M}$ in micropipette) was

\section{Intracellular, PGN cell}
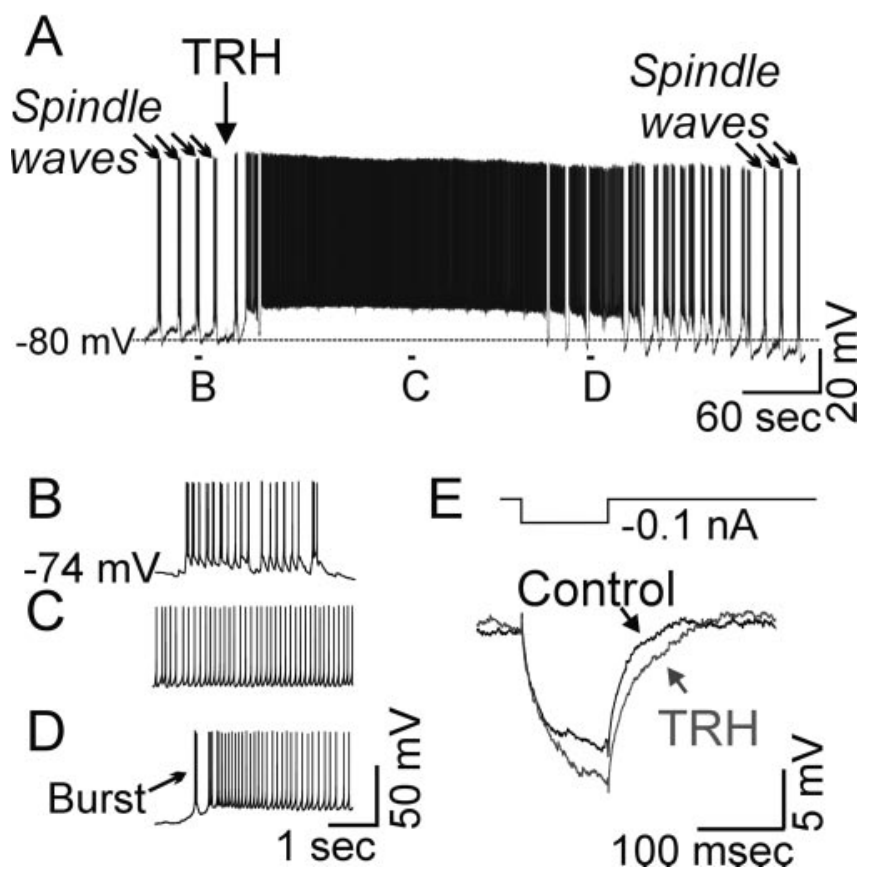

Figure 7. TRH depolarizes $\mathrm{PGN}$ neurons, shifting bursting discharge to tonic firing. $A$, Intracellular recording from a PGN neuron during local application of TRH. Spindle wave burst discharges are elicited in response to EPSP barrages arriving rhythmically before TRH. Local application of TRH (1 $\mu \mathrm{m}$ in micropipette) results in an $\sim 15 \mathrm{mV}$ depolarization, causing sudden termination of spindle waves and the replacement of bursts by tonic discharge. As the effect or TRH declines, sudden hyperpolarizations appear that are followed by rhythmic burst discharge and tonic activity. This "hyperpolarization-rhythmic bursting-tonic activity" pattern recurs several times until the cell finally hyperpolarizes and resumes the normal spindle-wave pattern. $B-D$, Expansion of portions of $A$. Note intracellularly recorded spontaneous spindle wave with burst superimposed on EPSP barrages $(B)$, TRH-induced tonic firing $(12 \mathrm{~Hz})(C)$, and tonic afterdischarge preceded by bursts $(D)$. $E$, TRH causes an increase in apparent input resistance in PGN neurons, as demonstrated by an increased voltage deflection in response to hyperpolarizing current pulses and after compensation for the change in membrane potential with the intracellular injection of d.c.

followed by a marked depolarization (average, $+13 \pm 5 \mathrm{mV} ; n=$ 10 of 10) (Fig. $7 A, C$ ), leading to the cessation of spindle bursts and their replacement by tonic action potential discharge. As the TRH-induced depolarization decreased, oscillatory cycles were observed that were associated with the repeated occurrence of a bistable behavior (Fig. 7A) in which there was a sudden hyperpolarization, followed by a rapid depolarization. The sudden depolarization caused the generation of one to three rhythmic burst discharges followed by tonic action potential activity (Fig. $7 A, D$ ). Gradually, the hyperpolarized portions of this bistable behavior became longer and the depolarized portions shorter, until finally a transition to pre-TRH baseline was obtained. A full recovery from the application of TRH to the PGN could take several minutes to $>10 \mathrm{~min}$. As could be observed in thalamocortical cells, a small $(1-2 \mathrm{mV})$, prolonged hyperpolarization sometimes followed the cessation of the depolarizing response to TRH (Fig. $7 A$ ). The TRH-induced depolarization of PGN neurons was accompanied by a small increase in input resistance (average, $+17 \pm 7 \% ; n=10$ of 10 ) (Fig. $7 E$ ) as evidenced by increased voltage deflections in response to hyperpolarizing current pulses after manual compensation for changes in membrane potential.

The properties of the TRH-induced depolarization of PGN neurons were further investigated by obtaining continuous cur- 
A

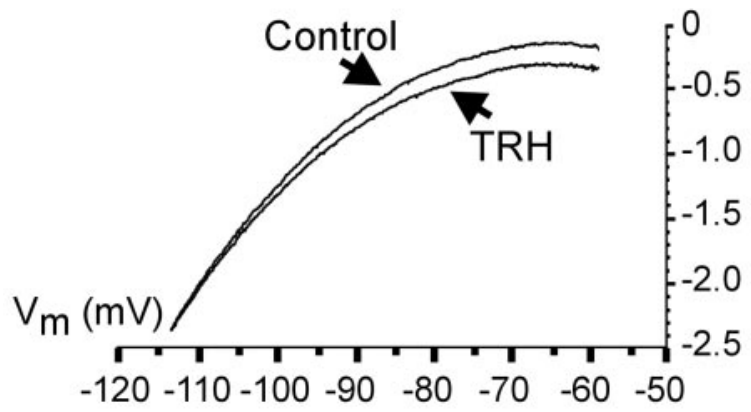

$B$

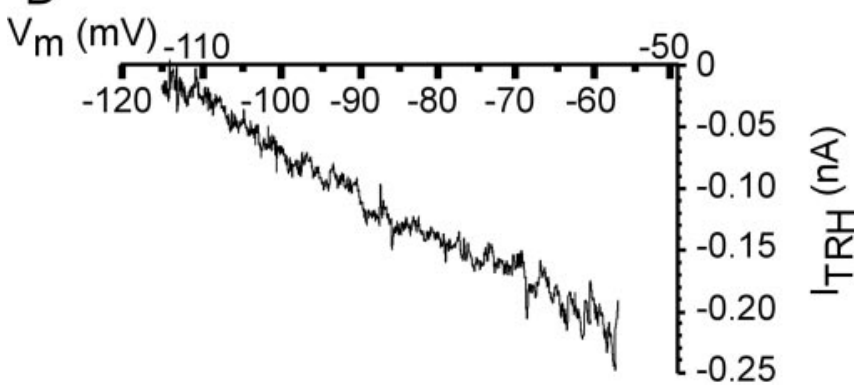

Figure 8. TRH induces an inward current with a reversal potential near $E_{\mathrm{K}} \cdot A$, Current versus voltage plot before and after the local application of TRH. $B$, Subtraction of the TRH plot from control reveals the TRH-induced current. TRH induces an inward current that exhibits a projected reversal potential of $-115 \mathrm{mV}$, which is near $E_{\mathrm{K}}$.

rent versus voltage $(I-V)$ plots between approximately -50 and $-120 \mathrm{mV}$ with single-electrode voltage clamp (Fig. 8). Local application of TRH ( $1 \mu \mathrm{M}$ in micropipette) to PGN cells resulted in an inward current, the amplitude of which decreased steadily with hyperpolarization. The difference in $I-V$ currents before and after the application of TRH yielded the TRH-sensitive component. The linear component of the TRH response was associated with a $4-5 \mathrm{nS}$ decrease in membrane conductance and exhibited an average extrapolated reversal potential of $-118 \pm 16 \mathrm{mV}(n=$ 6). This reversal potential is near $E_{\mathrm{K}}$ in $2.5 \mathrm{~mm}\left[\mathrm{~K}^{+}\right]_{\mathrm{o}}$ (McCormick and Wang, 1991), indicating that the TRH-mediated depolarization is most likely mediated by a decrease in a $\mathrm{K}^{+}$current.

\section{Discussion}

We present evidence that the neuropeptide TRH can potently control the state of thalamocortical activity through depolarization of both thalamocortical cells and GABAergic nRt/PGN neurons. No effect was seen on interneurons in the LGNd, although it should be noted that here we only investigated interneurons that fire tonically and are responsive to methylcholine; additional classes of interneurons may exist (Sanchez-Vives et al., 1996). These results demonstrate a novel role for TRH and suggest a mechanism of action for the sleep-modulatory and anti-epileptic properties observed in clinical and experimental studies.

The response of LGNd neurons to TRH has three distinct components. First, there is a sustained, moderate depolarization, sufficient to block or reduce rebound burst firing (Bal and McCormick, 1996). The increased apparent input resistance in thalamocortical cells and the reversal potential near $E_{\mathrm{K}}$ of the TRH response in PGN neurons indicates that these depolarizations result from reduction of a resting or "leak" $\mathrm{K}^{+}$conductance in both of these cell types. Although we did not directly measure the reversal potential of the TRH-induced depolarization in thalamocortical cells, the similarity of this response to that in PGN neurons suggests that it operates through the same mechanisms. Notably, in spinal cord neurons TRH elicits a slow depolarization involving a $\mathrm{K}^{+}$conductance (Kolaj et al., 1997). Recent reports implicate two-pore-domain $\mathrm{K}^{+}$channels as targets for TRH in brainstem neurons (Talley et al., 2000). Indeed, several thalamic neurotransmitters and peptides converge on this conductance, bringing thalamocortical neurons out of the burstfiring mode and closer to the threshold for tonic discharge (McCormick and Prince, 1986; McCormick and Wang, 1991), an action that has been suggested as central to the transition from sleep to waking (McCormick, 1992).

We also observed a prominent enhancement by TRH of the slow afterdepolarization that follows rebound $\mathrm{Ca}^{2+}$ spikemediated burst discharges (Bal and McCormick, 1993). Previous studies have attributed this ADP to a CAN cation current (Hasuo et al., 1990; Bal and McCormick, 1993; Partridge et al., 1994; Klink and Alonso, 1997; Zhu et al., 1999; Hughes et al., 2002), which is consistent with the present finding that the TRHenhanced ADP disappears when $\mathrm{Ca}^{2+}$ is replaced with $\mathrm{Sr}^{2+}$ [which mimics the electrotonic properties of the LTS (Shuba et al., 1991) but does not activate the CAN current (Bal and McCormick, 1993)]. The slow, noninactivating kinetics and amplifying excitatory properties (Partridge and Valenzuela, 1999) of the CAN current may provide for a sustained depolarized state in response to TRH. It has been demonstrated that reduction of the leak $\mathrm{K}^{+}$conductance in itself may increase the ADP (Hughes et al., 2002); however, the TRH-induced enhancement of the slow ADP described here could be observed also in the absence of an increased input resistance, suggesting that this effect is independent of changes in leak $\mathrm{K}^{+}$conductance and likely the result of direct actions on the CAN current. In preganglionic spinal neurons, TRH (in addition to its action on $\mathrm{K}^{+}$currents) increases a membrane conductance that reverses around $-40 \mathrm{mV}$ (Kolaj et al., 1997), which is consistent with a nonselective cation current. As in thalamic relay nuclei, the spinal cord expresses the TRHR2 receptor. Activation of the TRHR2 can produce large increases in $\left[\mathrm{Ca}^{2+}\right]_{\mathrm{i}}$ (Cao et al., 1998), which may activate CAN currents (Partridge et al., 1994; Partridge and Valenzuela, 1999). It is unlikely that the slow and steady depolarization of thalamocortical cells was caused solely by an enhancement of an afterdepolarizing current, because this steady depolarization did not require the presence of low-threshold $\mathrm{Ca}^{2+}$ spikes.

Last, the application of TRH to the LGNd resulted in the late arrival of $2 \mathrm{~Hz}$ rhythmic IPSP barrages in thalamocortical neurons, consisting of individual IPSPs arriving at 200-500 Hz. This activity correlates well with the rhythmic burst firing of GABAergic PGN neurons during the late stage of their response to TRH (Figs. 4, 7). This similarity suggests that local application of TRH in the LGNd resulted either in burst firing in PGN neurons through spillover into the PGN or, more likely, by the activation of PGN-like interneurons within the interlaminar zones of the LGNd (Sanchez-Vives et al., 1996).

Together, these excitatory actions of TRH on thalamocortical and nRt/PGN neurons provide an explanation for the network effects revealed with extracellular multiunit recordings. The concerted depolarization of many thalamocortical and nRt/PGN neurons would bring the network out of the rhythmic bursting mode that sustains spindle waves (as observed at TRH concentrations of $\geq 50 \mathrm{~nm}$ ). The paradoxically increased spindle-wave rate obtained with very low doses (10 nM) of TRH may be caused by a more limited depolarization of thalamic neurons, increasing their excitability while still maintaining the bursting mode, lead- 
ing to a faster, less organized oscillation. Cholecystokinin, another peptide capable of disrupting thalamic synchrony, in lower doses also paradoxically promotes oscillations (Cox et al., 1997), an action that was explained as increased recruitment of $\mathrm{nRt}$ neurons participating in the oscillatory cycle. These data suggest that increased levels of TRH may result in graded depolarization that can shift thalamic cells between three states: enhancement of spindles, block of spindles, and finally, with stronger depolarizations, induction of tonic, single-spike activity.

The excitatory responses to TRH within the thalamic network indicate that the peptide may play a role in switching the statedependent circuits in the forebrain from the rhythmic, synchronized signaling typical of slow-wave sleep to the stimulusoperated individual firing patterns that underlie sensory processing in the wake state. Indeed, intracerebroventricular administration of TRH dramatically reduces sleep time in rats (Hinkle et al., 2002). Furthermore, in canine narcolepsy, TRH analogs alleviate the hallmark symptoms of daytime sleepiness and cataplexy (Nishino et al., 1997). A site of action for these effects has not yet been described. We propose, based on the present data, that actions within the thalamocortical network may underlie, at least in part, the wake-promoting effects of TRH.

We also report that TRH suppressed the $2-3 \mathrm{~Hz}$ bicucullineinduced seizure-like discharge in the geniculate slice, a model of absence epilepsy (von Krosigk et al., 1993; Bal et al., 1995a,b; McCormick and Contreras, 2001). Importantly, clinical studies have identified TRH as an anticonvulsant in children with Lennox-Gastaut and West syndromes (Matsumoto et al., 1987; Takeuchi et al., 2001) and in animal models of epilepsy, including absence epilepsy (Ujihara et al., 1991; Momiyama et al., 1996). These likely represent central effects because, as also demonstrated for the sleep-modulating effects (Nishino et al., 1997), TRH doses sufficient to produce anticonvulsive protection do not significantly elevate peripheral thyroid hormone concentrations, and the anticonvulsant actions are not mimicked by activation of the thyroid axis (Nemeroff et al., 1975; Momiyama et al., 1996). TRH is distinct from most commonly used antiepileptic drugs because its actions may involve excitatory rather than inhibitory effects in the CNS (Takeuchi et al., 2001).

The lack of specific TRHR antagonists prevents us from ascribing the effects that we have observed to one of the two cloned TRHR subtypes; however, thalamocortical relay cells express TRHR2, whereas TRHR1 is mostly absent from the thalamic complex (Cao et al., 1998; Heuer et al., 2000; O'Dowd et al., 2000). Neither of these receptors is expressed at significant levels in the rodent nRt. These data, to the extent that they can be extrapolated to the ferret, suggest that although TRH may act on thalamocortical cells via TRHR2, the potent excitatory actions in the PGN are likely mediated by a novel, as yet uncharacterized TRHR. In culture systems, both TRHR1 and TRHR2 display desensitization (O'Dowd et al., 2000; Zaltsman et al., 2000), apparently through receptor internalization (Nussenzveig et al., 1993; Ashworth et al., 1995). Removal of TRHRs from the somatic cell membrane may explain why spindle waves reappeared even in the continued presence of TRH, as well as the attenuated responses to a second TRH application. Notably, desensitization to $\mathrm{TRH}$ occurred within a relatively short time span, similar to the internalization kinetics described in cultured cells (Ashworth et al., 1995). Such a mechanism would allow for the relatively rapid reduction and/or termination of TRH action.

$\mathrm{TRH}$ is expressed in the nRt/PGN from which it could be released onto relay cells as well as locally within the nRt/PGN itself, perhaps through axonal or dendrodendritic synapses (Ide,
1982; Cucchiaro et al., 1991; Uhlrich et al., 1991; Bal et al., 1995a,b; Sanchez-Vives et al., 1997). The natural functional effect of TRH in vivo will depend not only on its postsynaptic effects, but also on the circumstances under which it is released. Some neuropeptides are released preferentially during bursting or high-frequency stimulation (Lundberg et al., 1980; Edwards et al., 1982; Jan and Jan, 1982; Lundberg and Hökfelt, 1983). If TRH is released during burst-dominated events such as spindle waves or seizure activity, the release of this peptide may play a role in the cessation of these network oscillations and the promotion of tonic discharge. This possibility remains to be examined.

Once thalamocortical networks are in the depolarized and tonic discharge state, the release of TRH may decrease, because of the lack of burst firing, or there may be postsynaptic desensitization of neuronal responses, as observed here for prolonged applications of this peptide. If, however, TRH still exhibits a pronounced excitatory effect on $\mathrm{nRt} / \mathrm{PGN}$ neurons during the waking state, this may result in an increase in the inhibitory tone of thalamocortical cells, suppressing ongoing, background activity without the inhibition of sensory/motor-specific discharge. The exact role of TRH in the control of thalamocortical systems remains to be determined, although clearly it may be functionally important, especially in the generation and control of epilepsy and sleep disorders.

\section{References}

Aghajanian GK, Rasmussen K (1989) Intracellular studies in the facial nucleus illustrating a simple new method for obtaining viable motoneurons in adult rat brain slices. Synapse 3:331-338.

Ashworth R, Yu R, Nelson EJ, Dermer S, Gershengorn MC, Hinkle PM (1995) Visualization of the thyrotropin-releasing hormone receptor and its ligand during endocytosis and recycling. Proc Natl Acad Sci USA 92:512-516.

Bal T, McCormick DA (1993) Mechanisms of oscillatory activity in guineapig nucleus reticularis thalami in vitro: a mammalian pacemaker. J Physiol (Lond) 468:669-691.

Bal T, McCormick DA (1996) What stops synchronized thalamocortical oscillations? Neuron 17:297-308.

Bal T, von Krosigk M, McCormick DA (1995a) Synaptic and membrane mechanisms underlying synchronized oscillations in the ferret lateral geniculate nucleus in vitro. J Physiol (Lond) 483:641-663.

Bal T, von Krosigk M, McCormick DA (1995b) Role of the ferret perigeniculate nucleus in the generation of synchronized oscillations in vitro. J Physiol (Lond) 483:665-685.

Boler J, Enzmann F, Folkers K, Bowers CY, Schally AV (1969) The identity of chemical and hormonal properties of the thyrotropin releasing hormone and pyroglutamyl-histidyl-proline amide. Biochem Biophys Res Commun 37:705-710.

Broberger C, McCormick DA (2002) Inhibition of sleep spindles in the ferret thalamus by thyrotropin-releasing hormone (TRH). Soc Neurosci Abstr 28:840.6.

Burgunder JM, Heyberger B, Lauterburg T (1999) Thalamic reticular nucleus parcellation delineated by VIP and TRH gene expression in the rat. J Chem Neuroanat 17:147-152.

Burgus R, Dunn TF, Desiderio D, Guillemin R (1969) Molecular structure of the hypothalamic hypophysiotropic TRF factor of ovine origin: mass spectrometry demonstration of the PCA-His-Pro-NH2 sequence. C R Acad Sci Hebd Seances Acad Sci D 269:1870-1873.

Cao J, O’Donnell D, Vu H, Payza K, Pou C, Godbout C, Jakob A, Pelletier M, Lembo P, Ahmad S, Walker P (1998) Cloning and characterization of a cDNA encoding a novel subtype of rat thyrotropin-releasing hormone receptor. J Biol Chem 273:32281-32287.

Cox CL, Huguenard JR, Prince DA (1995) Cholecystokinin depolarizes rat thalamic reticular neurons by suppressing a $\mathrm{K}^{+}$conductance. J Neurophysiol 74:990-1000.

Cox CL, Huguenard JR, Prince DA (1997) Peptidergic modulation of intrathalamic circuit activity in vitro: actions of cholecystokinin. J Neurosci $17: 70-82$. 
Cucchiaro JB, Uhlrich DJ, Sherman SM (1991) Electron-microscopic analysis of synaptic input from the perigeniculate nucleus to the A-laminae of the lateral geniculate nucleus in cats. J Comp Neurol 310:316-336.

Debarbieux F, Brunton J, Charpak S (1998) Effect of bicuculline on thalamic activity: a direct blockade of IAHP in reticularis neurons. J Neurophysiol 79:2911-2918.

Deschênes M, Paradis M, Roy JP, Steriade M (1984) Electrophysiology of neurons of lateral thalamic nuclei in cat: resting properties and burst discharges. J Neurophysiol 51:1196-1219.

Domich L, Oakson G, Steriade M (1986) Thalamic burst patterns in the naturally sleeping cat: a comparison between cortically projecting and reticularis neurones. J Physiol (Lond) 379:429-449.

Edwards AV, Jarhult J, Andersson P-O, Bloom SR (1982) The importance of the pattern of stimulation in relation to the response of autonomic effectors. Stuttgart, Germany: Schattauer.

Hasuo H, Phelan KD, Twery MJ, Gallagher JP (1990) A calcium-dependent slow afterdepolarization recorded in rat dorsolateral septal nucleus neurons in vitro. J Neurophysiol 64:1838-1846.

Heuer H, Schafer MK, O’Donnell D, Walker P, Bauer K (2000) Expression of thyrotropin-releasing hormone receptor 2 (TRH-R2) in the central nervous system of rats. J Comp Neurol 428:319-336.

Hinkle PM, Pekary AE, Senanayaki S, Sattin A (2002) Role of TRH receptors as possible mediators of analeptic actions of TRH-like peptides. Brain Res 935:59-64.

Houser CR, Vaughn JE, Barber RP, Roberts E (1980) GABA neurons are the major cell type of the nucleus reticularis thalami. Brain Res 200:341-354.

Hughes SW, Cope DW, Blethyn KL, Crunelli V (2002) Cellular mechanisms of the slow $(<1 \mathrm{~Hz})$ oscillation in thalamocortical neurons in vitro. Neuron 33:947-958.

Huguenard JR, Prince DA (1994) Clonazepam suppresses GABABmediated inhibition in thalamic relay neurons through effects in nucleus reticularis. J Neurophysiol 71:2576-2581.

Huntsman MM, Porcello DM, Homanics GE, DeLorey TM, Huguenard JR (1999) Reciprocal inhibitory connections and network synchrony in the mammalian thalamus. Science 283:541-543.

Ide LS (1982) The fine structure of the perigeniculate nucleus in the cat. J Comp Neurol 210:317-334.

Jahnsen H, Llinás R (1984a) Voltage-dependent burst-to-tonic switching of thalamic cell activity: an in vitro study. Arch Ital Biol 122:73-82.

Jahnsen H, Llinás R (1984b) Electrophysiological properties of guinea-pig thalamic neurones: an in vitro study. J Physiol (Lond) 349:205-226.

Jan LY, Jan YN (1982) Peptidergic transmission in sympathetic ganglia of the frog. J Physiol (Lond) 327:219-246.

Klink R, Alonso A (1997) Ionic mechanisms of muscarinic depolarization in entorhinal cortex layer II neurons. J Neurophysiol 77:1829-1843.

Kolaj M, Shefchyk SJ, Renaud LP (1997) Two conductances mediate thyrotropin-releasing-hormone-induced depolarization of neonatal rat spinal preganglionic and lateral horn neurons. J Neurophysiol 78:1726-1729.

Kostopoulos G, Gloor P, Pellegrini A, Gotman J (1981) A study of the transition from spindles to spike and wave discharge in feline generalized penicillin epilepsy: microphysiological features. Exp Neurol 73:55-77.

Lechan RM, Wu P, Jackson IM, Wolf H, Cooperman S, Mandel G, Goodman RH (1986) Thyrotropin-releasing hormone precursor: characterization in rat brain. Science 231:159-161.

Lee KH, McCormick DA (1997) Modulation of spindle oscillations by acetylcholine, cholecystokinin and $1 S, 3 R$-ACPD in the ferret lateral geniculate and perigeniculate nuclei in vitro. Neuroscience 77:335-350.

Lee SH, Cox CL (2003) Vasoactive intestinal peptide selectively depolarizes thalamic relay neurons and attenuates intrathalamic rhythmic activity. J Neurophysiol 90:1224-1234.

Leresche N, Asprodini E, Emri Z, Cope DW, Crunelli V (2000) Somatostatin inhibits GABAergic transmission in the sensory thalamus via presynaptic receptors. Neuroscience 98:513-522.

Liu Z, Vergnes M, Depaulis A, Marescaux C (1991) Evidence for a critical role of GABAergic transmission within the thalamus in the genesis and control of absence seizures in the rat. Brain Res 545:1-7.

Lundberg JM, Hökfelt T (1983) Coexistence of peptides and classical transmitters. Trends Neurosci 6:325-333.

Lundberg JM, Anggard A, Fahrenkrug J, Hokfelt T, Mutt V (1980) Vasoactive intestinal polypeptide in cholinergic neurons of exocrine glands: functional significance of coexisting transmitters for vasodilation and secretion. Proc Natl Acad Sci USA 77:1651-1655.

Matsumoto A, Kumagai T, Takeuchi T, Miyazaki S, Watanabe K (1987) Clinical effects of thyrotropin-releasing hormone for severe epilepsy in childhood: a comparative study with ACTH therapy. Epilepsia 28:49-55.

McCarley RW, Benoit O, Barrionuevo G (1983) Lateral geniculate nucleus unitary discharge in sleep and waking: state- and rate-specific aspects. J Neurophysiol 50:798-818.

McCormick DA (1992) Neurotransmitter actions in the thalamus and cerebral cortex and their role in neuromodulation of thalamocortical activity. Prog Neurobiol 39:337-388.

McCormick DA, Bal T (1997) Sleep and arousal: thalamocortical mechanisms. Annu Rev Neurosci 20:185-215.

McCormick DA, Contreras D (2001) On the cellular and network bases of epileptic seizures. Annu Rev Physiol 63:815-846.

McCormick DA, Pape HC (1988) Acetylcholine inhibits identified interneurons in the cat lateral geniculate nucleus. Nature 334:246-248.

McCormick DA, Prince DA (1986) Acetylcholine induces burst firing in thalamic reticular neurones by activating a potassium conductance. Nature 319:402-405.

McCormick DA, Wang Z (1991) Serotonin and noradrenaline excite GABAergic neurones of the guinea-pig and cat nucleus reticularis thalami. J Physiol (Lond) 442:235-255.

Meis S, Munsch T, Pape HC (2002) Anti-oscillatory effects of nociceptin/ orphanin FQ in synaptic networks of the rat thalamus. J Neurosci 22:718-727.

Momiyama T, Ishihara K, Kimura K, Todo N, Fujita Y, Serikawa T, Sasa M (1996) Long-term anti-epileptic effects of chronic intake of CNK-602A, a thyrotropin-releasing hormone analogue, on spontaneously epileptic rats. Epilepsia 37:328-331.

Nemeroff CB, Prange Jr AJ, Bissette G, Breese GR, Lipton MA (1975) Thyrotropin-releasing hormone (TRH) and its beta-alanine analogue: potentiation of the anticonvulsant potency of phenobarbital in mice. Psychopharmacol Commun 1:305-317.

Nishino S, Arrigoni J, Shelton J, Kanbayashi T, Dement WC, Mignot E (1997) Effects of thyrotropin-releasing hormone and its analogs on daytime sleepiness and cataplexy in canine narcolepsy. J Neurosci 17:6401-6408.

Nussenzveig DR, Heinflink M, Gershengorn MC (1993) Agoniststimulated internalization of the thyrotropin-releasing hormone receptor is dependent on two domains in the receptor carboxyl terminus. J Biol Chem 268:2389-2392.

O’Dowd BF, Lee DK, Huang W, Nguyen T, Cheng R, Liu Y, Wang B, Gershengorn MC, George SR (2000) TRH-R2 exhibits similar binding and acute signaling but distinct regulation and anatomic distribution compared with TRH-R1. Mol Endocrinol 14:183-193.

Pape HC, McCormick DA (1995) Electrophysiological and pharmacological properties of interneurons in the cat dorsal lateral geniculate nucleus. Neuroscience 68:1105-1125.

Partridge LD, Valenzuela CF (1999) $\mathrm{Ca}^{2+}$ store-dependent potentiation of $\mathrm{Ca}^{2+}$-activated non-selective cation channels in rat hippocampal neurones in vitro. J Physiol (Lond) 521:617-627.

Partridge LD, Muller TH, Swandulla D (1994) Calcium-activated nonselective channels in the nervous system. Brain Res Brain Res Rev 19:319-325.

Sanchez-Vives MV, Bal T, Kim U, von Krosigk M, McCormick DA (1996) Are the interlaminar zones of the ferret dorsal lateral geniculate nucleus actually part of the perigeniculate nucleus? J Neurosci 16:5923-5941.

Sanchez-Vives MV, Bal T, McCormick DA (1997) Inhibitory interactions between perigeniculate GABAergic neurons. J Neurosci 17:8894-8908.

Segerson TP, Hoefler H, Childers H, Wolfe HJ, Wu P, Jackson IM, Lechan RM (1987) Localization of thyrotropin-releasing hormone prohormone messenger ribonucleic acid in rat brain in situ hybridization. Endocrinology 121:98-107.

Shuba YM, Teslenko VI, Savchenko AN, Pogorelaya NH (1991) The effect of permeant ions on single calcium channel activation in mouse neuroblastoma cells: ion-channel interaction. J Physiol (Lond) 443:25-44.

Steriade M, Contreras D (1998) Spike-wave complexes and fast components of cortically generated seizures. I. Role of neocortex and thalamus. J Neurophysiol 80:1439-1455.

Steriade M, Domich L, Oakson G (1986) Reticularis thalami neurons revis- 
ited: activity changes during shifts in states of vigilance. J Neurosci 6:68-81.

Steriade M, McCormick DA, Sejnowski TJ (1993) Thalamocortical oscillations in the sleeping and aroused brain. Science 262:679-685.

Sun QQ, Huguenard JR, Prince DA (2001a) Neuropeptide Y receptors differentially modulate G-protein-activated inwardly rectifying $\mathrm{K}^{+}$channels and high-voltage-activated $\mathrm{Ca}^{2+}$ channels in rat thalamic neurons. J Physiol (Lond) 531:67-79.

Sun QQ, Akk G, Huguenard JR, Prince DA (2001b) Differential regulation of GABA release and neuronal excitability mediated by neuropeptide Y1 and Y2 receptors in rat thalamic neurons. J Physiol (Lond) 531:81-94.

Sun QQ, Huguenard JR, Prince DA (2002) Somatostatin inhibits thalamic network oscillations in vitro: actions on the GABAergic neurons of the reticular nucleus. J Neurosci 22:5374-5386.

Sun QQ, Prince DA, Huguenard JR (2003) Vasoactive intestinal polypeptide and pituitary adenylate cyclase-activating polypeptide activate hyperpolarization-activated cationic current and depolarize thalamocortical neurons in vitro. J Neurosci 23:2751-2758.

Takeuchi Y, Takano T, Abe J, Takikita S, Ohno M (2001) Thyrotropin- releasing hormone: role in the treatment of West syndrome and related epileptic encephalopathies. Brain Dev 23:662-667.

Talley EM, Lei Q, Sirois JE, Bayliss DA (2000) TASK-1, a two-pore domain $\mathrm{K}^{+}$channel, is modulated by multiple neurotransmitters in motoneurons. Neuron 25:399-410.

Uhlrich DJ, Cucchiaro JB, Humphrey AL, Sherman SM (1991) Morphology and axonal projection patterns of individual neurons in the cat perigeniculate nucleus. J Neurophysiol 65:1528 -1541.

Ujihara H, Xie RM, Sasa M, Ishihara K, Fujita Y, Yoshimura M, Kishimoto T, Serikawa T, Yamada J, Takaori S (1991) Inhibition by thyrotropinreleasing hormone of epileptic seizures in spontaneously epileptic rats. Eur J Pharmacol 196:15-19.

von Krosigk M, Bal T, McCormick DA (1993) Cellular mechanisms of a synchronized oscillation in the thalamus. Science 261:361-364.

Zaltsman I, Grimberg H, Lupu-Meiri M, Lifschitz L, Oron Y (2000) Rapid desensitization of the TRH receptor and persistent desensitization of its constitutively active mutant. Br J Pharmacol 130:315-320.

Zhu JJ, Uhlrich DJ, Lytton WW (1999) Burst firing in identified rat geniculate interneurons. Neuroscience 91:1445-1460. 